\title{
Erratum to "Addition of Metanx in Pregabalin Partial Responders for Painful Diabetic Neuropathy"
}

\author{
Allen Mark Jacobs ${ }^{1 *}$, Dunlei Cheng' \\ ${ }^{1}$ Saint Louis University School of Medicine, Saint Louis, USA \\ ${ }^{2}$ University of Texas School of Public Health, Dallas, USA \\ Email: drjacobs0902@sbcglobal.net
}

Received 20 May 2013; revised 22 June 2013; accepted 30 June 2013

Copyright (C) 2014 by authors and Scientific Research Publishing Inc.

This work is licensed under the Creative Commons Attribution International License (CC BY).

http://creativecommons.org/licenses/by/4.0/

c) (i) Open Access

The original online version of this article (AM Jacobs, D Cheng 2014) Addition of Metanx in pregabalin partial responders for painful diabetic neuropathy, 2013, 3, 134-138

http://dx.doi.org/10.4236/jdm.2013.33020) was published in August, 2013. The author wishes to correct the following error:

Instead of Abstract Results: After 20 weeks, patients in the study group experienced greater pain relief compared to the control group, ( $87.5 \%$ vs. $25 \%$ respectively, $\mathrm{p}=0.005)$.

Should read Abstract Results: After 20 weeks, significantly more patients in the study group experienced pain relief compared to the control group ( $87.5 \%$ vs. $12.5 \%$, respectively, $\mathrm{p}=0.005)$. 
Scientific Research Publishing (SCIRP) is one of the largest Open Access journal publishers. It is currently publishing more than 200 open access, online, peer-reviewed journals covering a wide range of academic disciplines. SCIRP serves the worldwide academic communities and contributes to the progress and application of science with its publication.

Other selected journals from SCIRP are listed as below. Submit your manuscript to us via either submit@scirp.org or Online Submission Portal.
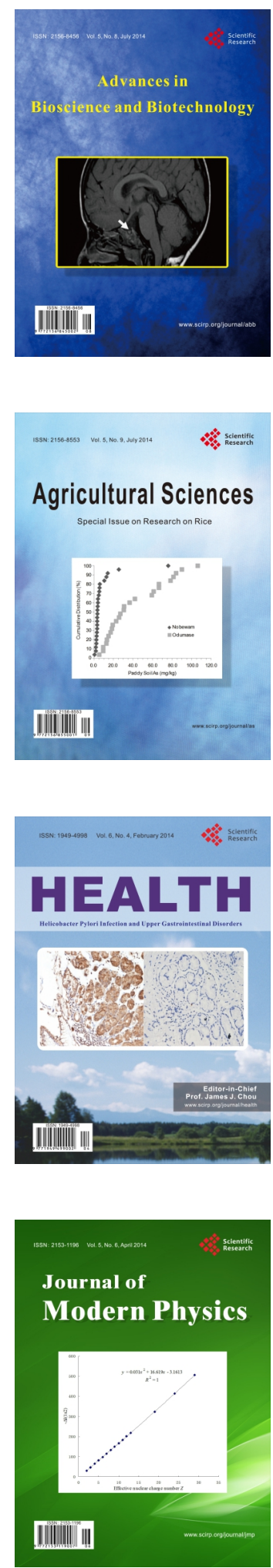
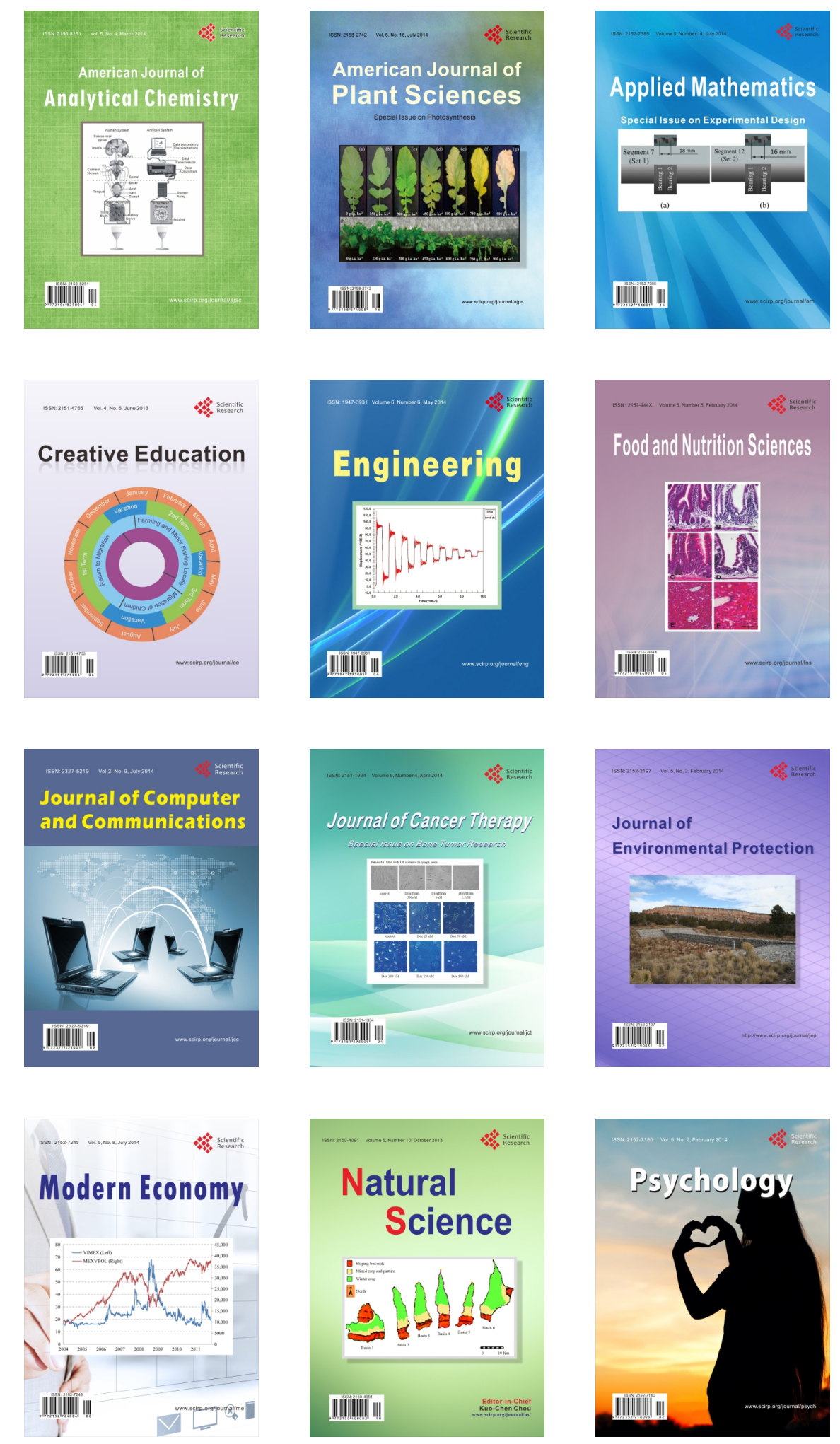